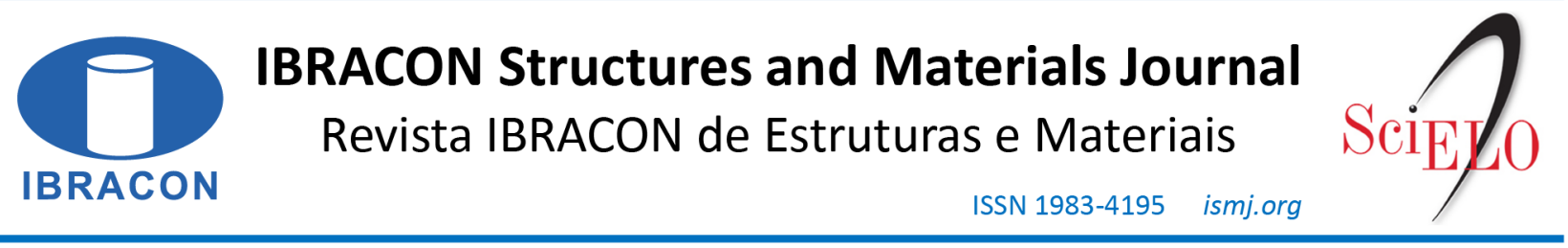

ORIGINAL ARTICLE

\title{
Concrete produced with recycled aggregate: a durability analysis for structural use
}

\section{Concreto produzido com agregado reciclado: uma análise de durabilidade visando uso em estruturas}

\author{
Lia Lorena Pimentel ${ }^{\mathrm{a}}$ (D) \\ Giovanna Falzetta Rizzo ${ }^{\mathrm{a}}$ \\ Ana Elisabete Paganelli Guimarães de Avila Jacintho ${ }^{a}$ \\ Patrícia Stella Pucharelli Fontanini ${ }^{b}$
}

\begin{abstract}
aPontifícia Universidade Católica de Campinas - PUC Campinas, Faculdade de Engenharia Civil, Programa de Pós-graduação em Sistemas de Infraestrutura Urbana, Campinas, SP, Brasil

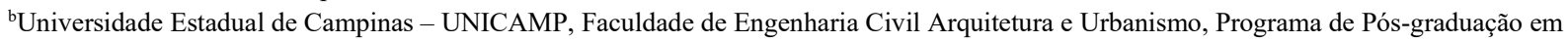
Engenharia Civil, Campinas, SP, Brasil
\end{abstract}

Received 26 March 2018

Accepted 17 April 2020

\begin{abstract}
Construction and Demolition waste (CDW) is already used in many European countries as recycled aggregates to produce concrete for structural purposes. In Brazil, its use is still restricted to concretes with no structural function. The consumption of aggregates for the production of concrete is very large, and enabling the use of recycled aggregates in the production of concrete is essential to transform the civil construction industry into a more sustainable one. This work aimed to study the parameters that affect the durability of $\mathrm{C} 30$ grade concrete, produced with different types of recycled aggregate. We defined four types of coarse aggregates for carrying out this work: the natural (AN), the concrete (ARCO), the cementitious materials (ARCI) and the treated cementitious materials (ARCI Treated). We adopted 30\% substitution content of natural aggregate for recycled aggregates. The treatment of the ARCI aggregate consisted of the application of water and cement solution, aiming to reduce its water absorption capacity. We determine the physical and mechanical characteristics of the concrete, in addition to carrying out indirect measurement tests of durability, by determining the permeability to air, penetration and migration of chloride ions, and determination of the carbonation depth. The results indicate that the concrete using the ARCO type aggregate, produced with $100 \%$ crushed concrete, presented characteristics like the reference concrete, indicating the possibility that it can be applied to reinforced concrete structures. As for the ARCI type aggregate, it presented inferior results when compared to the concrete reference for the tests of indirect measurement of durability, however, the concrete displayed good mechanical properties. The concrete produced with the treated ARCI did not perform better than the concrete with ARCI for most of the evaluated characteristics, indicating that the proposed treatment was not adequate.
\end{abstract}

Keywords: durability, construction waste, permeability.

Resumo: Os resíduos de construção civil (RCC) já são utilizados em muitos países da Europa como agregados reciclados para a produção de concreto com fins estruturais, no Brasil a sua utilização ainda é restrita a concretos sem função estrutural. O consumo de agregados para produção de concreto é muito grande, viabilizar a utilização de agregados reciclados na produção de concreto é fundamental para tornar a construção civil mais sustentável. Este trabalho teve como objetivo estudar os parâmetros que afetam a durabilidade do concreto de classe $\mathrm{C} 30$, produzido com diferentes tipos de agregado reciclado. Foram definidos quatro tipos de agregados graúdos para a realização deste trabalho, o natural (AN), o de concreto (ARCO), o cimentício (ARCI) e o cimentício tratado (ARCI Tratado) e foi fixado um teor de substituição do agregado natural pelos agregados reciclados de $30 \%$. O tratamento do ARCI consistiu em aplicação de uma solução de água e cimento, visando a redução de sua capacidade absorção de água. Foram determinadas as características físicas e mecânicas dos concretos, além de ensaios de medição indireta da durabilidade, através da determinação da permeabilidade ao ar, penetração e migração de cloreto e carbonatação. Os resultados indicam que o concreto

Corresponding author: Lia Lorena Pimentel. E-mail: lialp@puc-campinas.edu.br

Financial support: São Paulo Research Foundation, grant 2014/20486-8.

Conflict of interest: Nothing to declare.

This is an Open Access article distributed under the terms of the Creative Commons Attribution License, which permits unrestricted use, distribution, and reproduction in any medium, provided the original work is properly cited. 
utilizando o agregado tipo ARCO, produzido com 100\% de concreto britado, apresentou características similares ao concreto referência, indicando a possibilidade de ser aplicado em estruturas de concreto armado. Quanto ao ARCI, os resultados obtidos foram inferiores quando comparados ao concreto referência para os ensaios referentes a medição indireta da durabilidade, porém, o traço apresentou bom comportamento mecânico. O concreto produzido com o ARCI Tratado não apresentou melhor desempenho do que o concreto com ARCI para a maioria das características avaliadas, indicando que o tratamento proposto não foi adequado.

Palavras-chave: durabilidade, resíduo de construção, permeabilidade.

How to cite: L. L. Pimentel, G. F. Rizzo, A. E. P. G. A. Jacintho, and P. S. P. Fontanini, "Concrete produced with recycled aggregate: a durability analysis for structural use," Rev. IBRACON Estrut. Mater., vol. 13, no. 6, e13613, 2020, https://doi.org/10.1590/S1983-41952020000600013

\section{INTRODUCTION}

Currently, the construction industry is one of the human activities that most affects the environment [1]. McGinnis et al. [2] stated that the production of natural aggregates is those that most impact the environment, since for the concrete mixture, about $50 \%$ of its total volume is natural aggregate.

The recycling of construction and demolition waste for use as aggregates in the production of concrete would not only decrease the consumption of natural aggregates, but also reduce energy consumption, transportation costs and, consequently, the emission of polluting gases [3], [4].

Civil construction waste is identified by the European Union as a priority for reuse and recycling, as it represents approximately $30 \%$ of the solid waste generated. The authors estimated that $46 \%$ of the waste resulting from civil construction is recycled and reused, but they point out large variations between different countries [5]. According to the Panorama of Solid Waste of the State of São Paulo [6], the percentage of civil construction waste within solid waste is variable and difficult to determine, as the percentage varies according to the characteristics of the construction and the economic development of each region. Due to the high variability in the composition of civil construction waste, which consequently generates different types of recycled aggregates, the use of these materials in the production of concrete for structural purposes is difficult, since the variability of recycled aggregates results in uncertainty about the characteristics of the concrete produced with this material.

Currently, each country generally has its regulatory standard for the use of recycled aggregates, with its own nomenclature, defining what the types of aggregates are, and the maximum and minimum levels of each material that comprise it. Some standards prescribe the contents of substitution of natural aggregates for recycled ones in the production of concrete. In the United Kingdom, recycled aggregates are divided into two groups (RA-recycled aggregate and RCA - recycled concrete aggregate), according to their composition. Aggregates classified as RA are limited to the production of concrete with a maximum strength class of 16 to $20 \mathrm{MPa}$. Aggregates classified as RCA, on the other hand, can be used for concretes with structural functionality, since the strength class varies from 40 to $50 \mathrm{MPa}$. However, the replacement of natural aggregates with recycled aggregates is restricted to $20 \%$ [7].

Also, according to Gonçalves and Brito [7], in Portugal the use standard for recycled aggregates is similar to that of Germany. There recycled aggregates are divided into three groups, namely: RCA (recycled construction aggregate), which presents in its constitution concrete and masonry elements, this aggregate can only be used for concrete without structural purposes. The ARB1 (recycled concrete aggregate with a minimum of $90 \%$ concrete in its composition) and ARB2 (recycled concrete aggregate with a minimum of $70 \%$ concrete in its composition), which can be partial substitutes, with a maximum replacement content of $25 \%$ and $20 \%$, respectively, of natural aggregates. In addition to the replacement content, the standard establishes the maximum strength class of concrete at C40 / $50 \mathrm{MPa}$ for ARB1 and C35 / $45 \mathrm{MPa}$ for ARB2. The Australian Government allows the use of up to 30\% recycled aggregates in the concrete mix for structural purposes [1]. In Brazil, the technical standard NBR 15116 [8] which regulates the quality and use of recycled aggregate, allows its use in mixing concrete that is not used for structural purposes. This same standard classifies recycled aggregates as aggregate of concrete waste (ARC), which in its large fraction, must have at least $90 \%$ by mass of fragments based on Portland cement and rocks, and mixed residue aggregate (ARM), which in its large fraction, must have less than $90 \%$ by mass of fragments based on Portland cement and rocks. The type of aggregate added to the concrete mix has a great influence on its properties. Modifying the physical and mechanical properties of the concrete, such as its strength, water absorption capacity and porosity, can influence its durability [9]. Therefore, the study of the characteristics of the recycled aggregates that will be used in the mixing of the concrete is necessary and extremely important.

According to Gonçalves and Brito [7], concrete produced from recycled aggregates presents different characteristics from concrete produced with natural aggregates, and these differences are linked to the type of recycled aggregate used in the mixture. 
The mechanical properties of concrete produced from recycled aggregates decreases by 15 to $30 \%$ from the values obtained by conventional concrete, depending directly on the type of aggregate used. The greater the resistance of the concrete used in the production of the recycled aggregate, the better the quality of the aggregate and, consequently, the lesser the influence that these aggregates will have on the characteristics of the new concrete [10].

Initially, research on the effects caused by the replacement of natural aggregate with recycled aggregate was based only on the compressive strength that concrete using recycled aggregate could achieve, or on their economic viability. Since the beginning of such research, there has been increased interest in the mixing of recycled aggregate with concrete for structural purposes. For this reason, research has become more complex, introducing new variables, such as durability [11].

Durability refers to the ability of a structure to resist environmental influences of the installation site, throughout the expected life of the structure [12], i.e., "the effective period of time during the which structure meets the project's performance requirements, without unforeseen maintenance and repair actions" [13].

The durability of concrete can be attributed, for the most part, to the difficulty of penetrating aggressive agents in the concrete pore network [14].

The loss of the useful life of the reinforced concrete structure is due to the corrosion of the reinforcement, through attacks of deteriorating agents on the structure itself. Zhang and Shao [15] point out that corrosion of steel is one of the main problems in reducing the durability of the structure.

According to Santos [16], the durability of concrete is related to the mechanisms of fluid transport within the material since all possible mechanisms of deterioration of concrete structures involve gaseous or liquid transport processes. The dynamics of mass transport is determined by the interaction between the percolating fluid and the porous structure of the concrete. This interaction, depending on the fluid displacement by the pore structure, can occur in three different ways: diffusion (displacement due to a difference in concentration), capillarity (the result of capillary movements in the pores of the concrete opened to the medium) and permeability (flow under pressure differential).

Permeability is linked to the structure of the cement paste, to the aggregate and to the paste-aggregate interface, which determine the ease with which fluids and gases enter the structure. The lower the permeability of the concrete, the lower the penetration of aggressive agents into the interior concrete [17].

According to Ollivier and Vichot [14], the corrosion of concrete reinforcement is induced by two different phenomena: carbonation, the entry of carbon dioxide present in the atmosphere, and the penetration of chloride substances through the pores of the concrete, reaching the reinforcement.

The reduction in $\mathrm{pH}$ caused by carbonation accelerates corrosion of the reinforcements, since the chloride ions needed in the concrete to start the deterioration process are reduced [17].

Recycled aggregate generally has a greater water absorption capacity than natural aggregate due to its own porosity, which may change the properties of the concrete increasing its permeability, decreasing its mechanical resistance and, consequently, reducing its useful life.

To date, the mixing of recycled aggregates with concrete for structural purposes has been studied and has found that it is necessary to evaluate properties such as air permeability, water absorption capacity, among others [18]-[20].

The expansion in the field of consumption of the use of these materials is only possible through the development of continuous research to undo the negative concepts of the use of construction waste and to prove its full potential [21].

The objective of this work is to study the parameters that affect the durability of class $\mathrm{C} 30$ concrete that is produced with different types of recycled aggregate, to evaluate its mechanical and physical characteristics as well as the parameters that are directly linked to the durability of concrete structures after being exposed to adverse conditions. A treatment was also proposed for the recycled cementitious aggregate, aiming to reduce its water absorption capacity.

\section{MATERIALS AND EXPERIMENTAL PROGRAM}

The methodology for the development of the work was experimental and included the characterization of the materials, the dosage of the concrete, and the mechanical and physical evaluation. Indirect tests were used to evaluate durability.

\subsection{Materials - preparation and characterization}

We opted for the use of two types of recycled aggregate, one from the recycling plant and the other produced by crushing specimens in the laboratory. The recycled concrete aggregate (ARCO) was produced by crushing concrete specimens with strength classes between 30 to $50 \mathrm{MPa}$. 
The recycled cement aggregate (ARCI) is the aggregate classified by NBR 15116 [8] as ARC, with a high percentage, more than $90 \%$ of particles based on Portland cement and rocks.

The treated cementitious recycled aggregate (ARCI-treated) is ARCI aggregate, which has undergone a treatment to reduce its water absorption capacity. This aggregate was an impregnated with a water and cement solution with the proportion of $45 \mathrm{~kg}$ of cement per cubic meter of recycled aggregate. The amount of water needed for the treatment was defined according to the water absorption capacity of the ARCI, to ensure that the entire cement paste was absorbed.

To carry out the treatment, the water and cement were mixed in a concrete mixer for 15 seconds, then the recycled ARCI aggregate was added, mixing it for another 120 seconds. After mixing, the treated recycled aggregate was maintained cured in a closed plastic bag for 28 days before use, and 24 hours after treatment, the bags were stirred to avoid conglomerate of particle. This procedure was proposed by Perea and Alvarado [22].

The other aggregates used were the natural fine aggregate, from rivers, and the natural coarse aggregate of basaltic origin (AN). The cement used was that of high initial strength (CPV-ARI). The ADVACAST 525 superplasticizer additive was used to maintain the consistency of all mixtures produced at $6.5 \pm 1 \mathrm{~cm}$.

The characteristics of the aggregates were determined according to test procedures standardized by the NBR 7211 [23] and NBR 15116 [8] standards for natural and recycled aggregates. Table 1 presents the results obtained.

Table 1. Characteristics of the aggregates

\begin{tabular}{|c|c|c|c|c|c|c|}
\hline Aggregates & Standard & Natural Sand & Natural Coarse & ARCO & ARCI & ARCI Treated \\
\hline Specific mass $\left(\mathrm{g} / \mathrm{cm}^{3}\right)$ & NBR NM 52 [24] / NBR NM 53 [25] & 2.52 & 2.87 & 2.36 & 2.41 & 2.42 \\
\hline Water absorption $(\%)$ & NBR NM 52 [24]/ NBR NM 30 [26] & 2.76 & 1.35 & 7.34 & 7.35 & 6.75 \\
\hline Crushing Strength $(\%)$ & NBR $9938[27]$ & & 14.36 & 25.79 & 24.50 & 24.24 \\
\hline Max aggregate size $(\mathrm{mm})$ & NBR NM 248 [28] & 6.3 & 25 & 25 & 25 & 25 \\
\hline
\end{tabular}

The natural sand had a fine modulus of 3.01. It was observed that the water absorption capacity of the recycled aggregates was much higher than that of the natural aggregate, and that the treatment applied to the recycled aggregate ARCI promoted a small reduction in the water absorption capacity. Regarding the crushing strength of the aggregate, the test showed that there was no difference between the recycled aggregates and they were all less resistant than the natural aggregate.

\subsection{Concrete mix design}

A concrete mix with a strength class of $30 \mathrm{MPa}$ was defined using the IPT mix design method [29]. For this study, the replacement percentage of natural aggregate for recycled, $30 \%$, was defined for each of the three types of recycled aggregates. The correction of aggregate volume was made according to the difference between the specific mass of the natural aggregate and that of the recycled aggregates.

The definition of the percentage content for this study was decided based on prior studies [30], [31] and the standards that were cited by [1], [7]. In some cases, authors [4], [32], [19] have used contents of $50 \%$ and $100 \%$ for replacement, but the results obtained in most cases have not been favorable, so the $30 \%$ replacement content was defined for this work.

Table 2 shows the unitary mixes - by mass, the nomenclature adopted for each mix, the cement consumption and the respective percentage of additive used.

Table 2. Concrete mass unit mix proportions

\begin{tabular}{ccccccccc}
\hline Concrete & $\begin{array}{c}\text { Replacement } \\
\text { content. }\end{array}$ & $\mathbf{C}$ & $\begin{array}{c}\text { Natural } \\
\text { Sand }\end{array}$ & $\begin{array}{c}\text { Natural } \\
\text { Coarse }\end{array}$ & $\begin{array}{c}\text { Recycled } \\
\text { aggregate }\end{array}$ & $\mathbf{a} / \mathbf{c}$ & $\mathbf{S . ~ A . * ( \% )}$ & $\begin{array}{c}\text { Cc } * * \\
\left(\mathbf{k g} / \mathbf{m}^{3}\right)\end{array}$ \\
\hline T REF & 0 & 1 & 2.71 & 3.79 & 0 & 0.6 & 0.4 & 308.5 \\
\hline T ARCO & $30 \%$ & 1 & 2.71 & 2.65 & 1.00 & 0.6 & 0.4 & 308.5 \\
\hline T ARCI & $30 \%$ & 1 & 2.71 & 2.65 & 1.02 & 0.6 & 0.3 & 308.5 \\
\hline T ARCI Treated & $30 \%$ & 1 & 2.71 & 2.65 & 1.02 & 0.6 & 0.5 & 308.5 \\
\hline
\end{tabular}

*S.A. - Superplasticizer Additive; **Cement Consumption 
After the production of the concrete, the specimens were kept in a humid chamber for 28 days. After that period, some of the specimens were placed outside to be exposed to the weather.

The other specimens were immersed in saline solution, with a concentration of $4 \% \mathrm{NaCl}$, the purpose of which was to evaluate the response of the concrete to chemical attack. The volume of liquid used inside the containers was four times greater than the volume of the specimens inserted into them. The specimens that were exposed to the weather and those submerged in saline solution remained in these conditions until the end of the test period.

\subsection{Concrete properties}

The consistency assessment was made through NBR NM 67 [33] and specific gravity through NBR 9833 [34]. Table 3 presents the concrete properties in the hardened state and the respective test standard method.

Table 3. Tests for characterization of concrete.

\begin{tabular}{cc}
\hline Tests performed & Standard Method \\
\hline Resistance to axial compression & NBR 5739 [35] \\
\hline Modulus of elasticity & NBR 8522 [36] \\
\hline Water absorption capacity by immersion & NBR 9779 [38]23 \\
\hline Capillary water absorption capacity & Adaptation of the methodologies used by Omrane et al. [3], \\
Chloride penetration & França [39], Kim et al. [40], Real et al. [41]: \\
\hline Air and water permeability (Porosiscope) & Manual Porosiscope [42] \\
\hline Carbonation & Adaptation of the methodologies used by Perea and Alvarado [22], \\
\hline Chloride migration & NBR 7211 [23], Valls and Vàzquez [43], Gandía-Romero [44]: \\
\hline
\end{tabular}

\subsection{Indirect durability indicators}

\subsubsection{Determination of carbonation depth}

To determine the depth of carbonation, after 180 days of exposure to the weather, the specimens were cut and placed for one day in an oven for complete drying. Then, a phenolphthalein solution, with a concentration of $1 \%$, was sprayed on the cutting surface. After spraying, photographic recording of the surfaces was performed and, as shown in Figure $1 \mathrm{~A}$, the distance from the camera to the specimen and the location lighting were standardized. This apparatus was also used to photograph the specimens used in the chloride penetration test. Figure 1B shows an example of a specimen after spraying phenolphthalein.

A

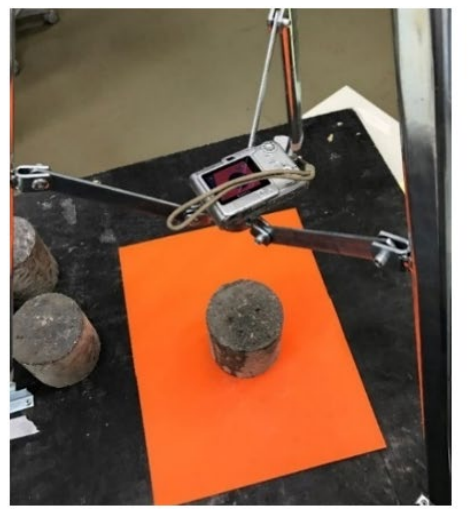

$\mathbf{B}$

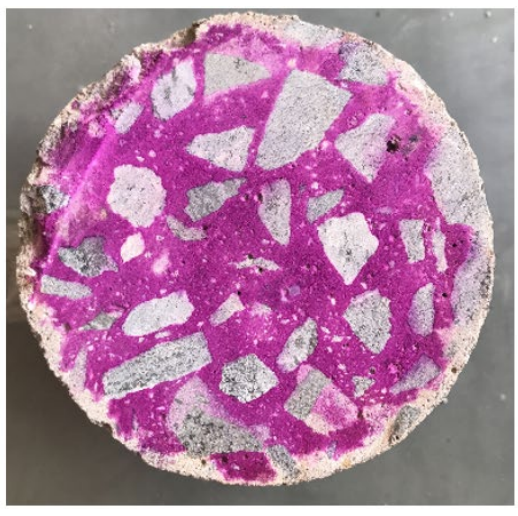

Figure 1. Test method of carbonation depth. A. Apparatus used to take the photographs. B. Specimen after spraying phenolphthalein. 
The photographs were loaded into the AutoCAD ${ }^{\circledR}$ program, which facilitated the determination of the carbonated area. From this value, the average thickness of carbonation was calculated using Equations 1 and 2:

$$
A_{\text {carbonated }}=A 10-A(10-e)
$$

$$
0.786 e^{2}-15.71 e+A_{\text {carbonated }}=0
$$

where A10 is the cross-sectional area of the specimen; and A $(10-\mathrm{e})$ is the area of the circle minus the carbonated thickness. With the carbonated area obtained in Equation 1, using the Bhaskára formula, the second-degree equation was defined for calculating the carbonation thickness (Equation 2).

\subsubsection{Determination of the chloride penetration depth}

After 180 days, the specimens immersed in saline solution were cut in half, repeating the procedure performed to determine the carbonation of the concrete. With the specimens at room temperature, a $0.3 \mathrm{M}$ silver nitrate solution was sprayed onto the cutting surface. Photographic records of the surfaces were taken, and analysis of the images was also performed to determine the depth of chloride penetration. The average chloride penetration thickness was calculated according to Equations 1 and 2.

\subsubsection{Determination of air permeability}

After 210 days, the specimens were tested to determine the surface permeability using Porosiscope equipment, which is shown in Figure 2. The air was pressurized on a concrete surface with a pressure of $55 \mathrm{kPa}$. The equipment timer determined how many seconds it took for the pressure to drop to $50 \mathrm{kPa}$.

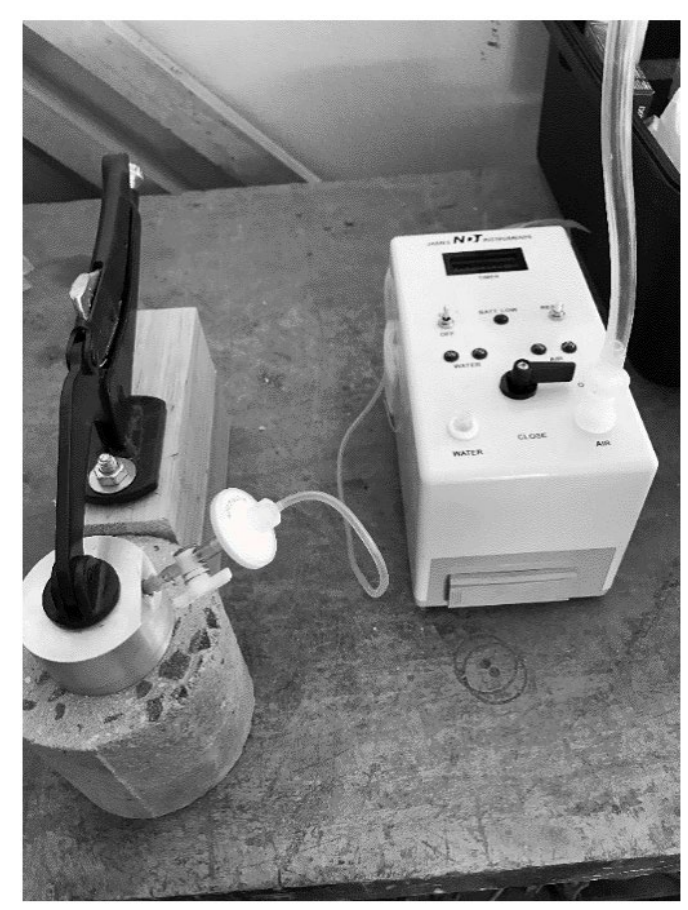

Figure 2. Porosiscope equipment. 
The permeability was determined according to the time that the air took to travel through the pores and into the concrete, by decreasing the pressure in the device fixed on the surface of the specimen. The equipment manual determines the classification of concrete according to the time required to lose pressure [42], as shown in Table 4 .

Table 4. Material classification according to permeability.

\begin{tabular}{ccc}
\hline Quality Category & Time(s) & Protection Quality \\
\hline 0 & $<30$ & Poor \\
\hline 1 & $30-100$ & Moderate \\
\hline 2 & $100-300$ & Satisfactory \\
\hline 4 & $300-1000$ & Good \\
\hline
\end{tabular}

Fonte: ASTM C 1202-05 [46]

\subsubsection{Chloride migration}

The chloride migration test was based on the methodology of Medeiros [45] and is outlined in Figure 3. The migration cells were assembled with PVC tubes, as this is a material resistant to aggressive media [42]. The two compartments, anodic and cathodic, were separated by a concrete sample with a thickness of $5 \mathrm{~cm}$. Distilled water was placed in the anode compartment, and in the other, a solution with $1 \mathrm{M} \mathrm{NaCl}$. A potential difference of $12 \mathrm{~V}$ was applied by an external voltage source, connected by electrodes with lengths of approximately $40 \mathrm{~cm}$.

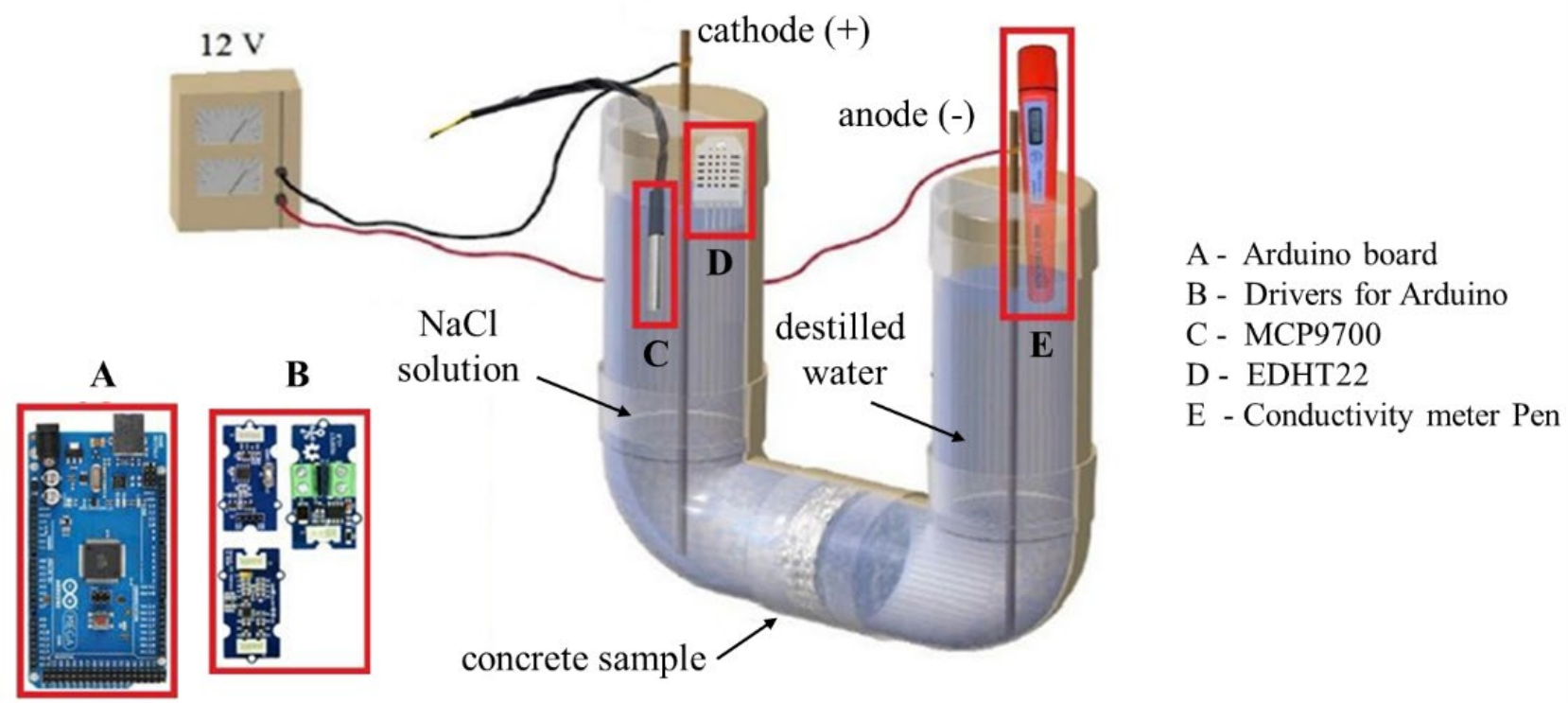

Figure 3. Scheme of chloride migration test adapted from Medeiros [45]

Like Medeiros [45], in addition to the concentration of chloride in the anode compartment, the temperature, electric current, conductivity and time necessary for the solutions to be chemically stabilized were also monitored. All data were collected by sensors and controlled by an Arduino board (A), which collects the data and transmits it to a memory card. Acting with the Arduino board (A), the drivers for Arduino (B) were: i) Current sensor, ii) Channel selector and iii) a digital device used to choose the channel.

The acquisition system selected the channel through digital outputs, and the SD card stored this data, which was made available in an Excel spreadsheet.

The electrical conductivity reading was performed using an Instrutherm model CD-880 Conductivity meter Pen (E). The internal temperature of the liquid was collected by the MCP 9700 sensor (C) and the DHT22 (D) sensor measured the humidity and temperature above the liquid level. 
To make the correlation between chloride content and conductivity, a correlation curve was produced (Figure 4). The obtained $\mathrm{R}^{2}$ was 0.9867 , thus showing a strong correlation between conductivity and chloride concentration.

In this test, the peak current in $\mathrm{mA}$ and the concentration of chloride in the anode compartment —as a function of time (in seconds) were determined.

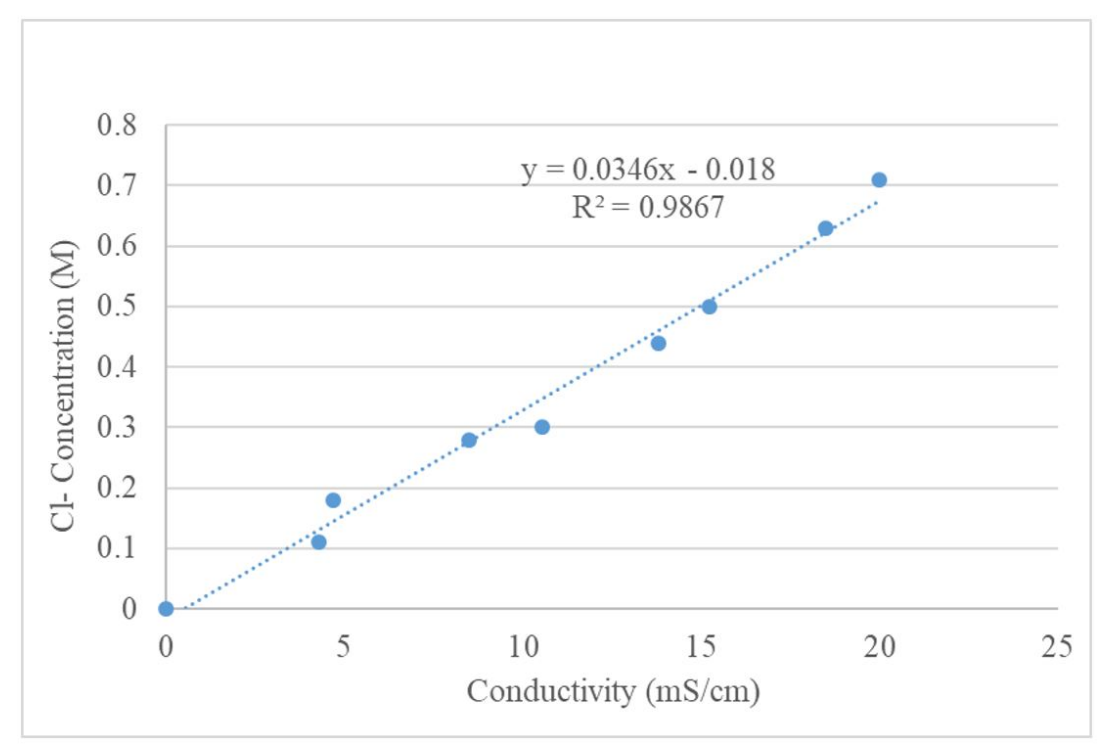

Figure 4. Calibration line between chloride concentration $(\mathrm{M})$ and conductivity $(\mathrm{mS} / \mathrm{cm})$.

\subsection{Results analysis}

To carry out the statistical analysis of the mechanical characteristics of the concrete, some procedures were conducted. First, to verify whether the characteristics of the data met the assumptions of MANOVA (Multivariate Analysis of Variance), normality was assessed by the Shapiro-Wilk test, and homogeneity of variance by the Bartlett test. After verification and validation of the data, a MANOVA could be performed. This analysis was performed for the mechanical characteristics of the concrete, produced at 7, 28, 90, and 180 days after immersion in saline solution. Physical characteristics were also analyzed, including water absorption capacity by immersion and water absorption capacity by capillarity.

\section{RESULTS AND DISCUSSIONS}

\subsection{Fresh concrete characteristics}

Table 5 presents the results of the tests carried out on the concrete in its fresh state. The use of superplasticizer additive ensured $65 \mathrm{~mm}$ consistency, defined as standard. It was observed that the reference concrete (T REF) presented a specific gravity that was greater than the other concretes, which can be explained by the specific mass of the natural coarse aggregate, shown in Table 1 to be greater than that of the recycled coarse aggregates.

Table 5. Fresh concrete characteristics.

\begin{tabular}{ccc}
\hline Concrete & Slump Test $\mathbf{( c m )}$ & Specific $\mathbf{m a s s}\left(\mathbf{g} / \mathbf{c m}^{\mathbf{3}}\right)$ \\
\hline T REF & 6.5 & 2.50 \\
\hline T 30 ARCO & 6.5 & 2.44 \\
\hline T 30 ARCI & 7.0 & 2.44 \\
\hline T 30 ARCI Treated & 6.5 & 2.37 \\
\hline
\end{tabular}




\subsection{Mechanical properties}

The mechanical properties that were evaluated for concrete in the hardened state were the resistance to axial compression and the modulus of elasticity. Figure 5 shows the results of resistance to axial compression, through which all concrete mixtures reached the proposed strength class of $30 \mathrm{MPa}$.

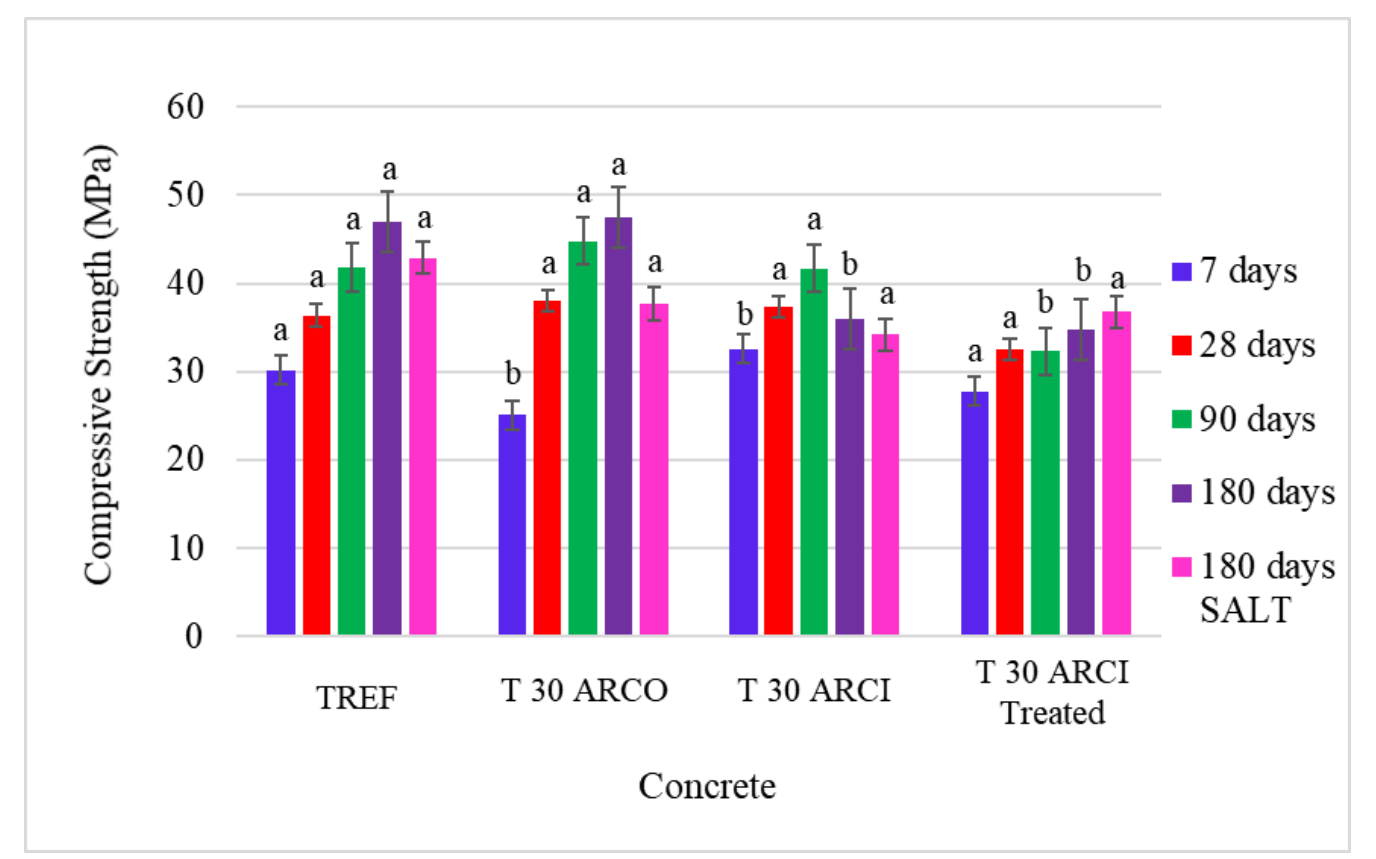

Figure 5. Results of resistance to axial compression.

At 28 days (post saline solution immersion), all concrete showed resistance to axial compression that were statistically similar to each other.

This behavior was not observed at 90 and 180 days. At 90 days, T 30 ARCO and T 30 ARCI showed similar behavior when compared to T REF, while T 30 ARCI Treated showed statistically different results and were thus inferior to the other concrete. At 180 days, T 30 ARCI showed a decrease in its resistance to axial compression, becoming statistically similar to T $30 \mathrm{ARCI}$ Treated, whereas T REF and T $30 \mathrm{ARCO}$ presented results that were statistically similar to each other.

After 180 days of saline immersion, all concrete showed similar behavior. It is worth mentioning that when the results of the resistance to axial compression after immersion in saline solution were compared with the results at 180 days, there were decreases in the results of resistance for T REF, T $30 \mathrm{ARCO}$ and T $30 \mathrm{ARCI}$, a behavior that was not observed for T $30 \mathrm{ARCI}$ Treated. Silva and Andrade [30] obtained loss in axial compression resistance for concretes that used only recycled aggregate when compared to the reference concrete; this behavior was improved by the addition of fly ash.

On the other hand, by crushing $80 \mathrm{MPa}$ strength class concrete, Afroughsabet et al. [4] produced recycled aggregates when used in the production of concrete with a $50 \%$ substitution content, and showed results superior to the reference concrete. When this substitution content reached $100 \%$, the results of resistance to axial compression obtained were similar to that of the reference concrete. The authors also point out that when the recycled aggregates produced started from a 40 MPa concrete, the same behavior was not observed, and the results of resistance to axial compression were lower than the reference concrete. In this study, the replacement of $30 \%$ of the natural aggregate with the recycled concrete aggregate (ARCO) produced from concrete with resistance between $\mathrm{C} 30$ and $\mathrm{C} 50$, did not affect the resistance to axial compression when compared to T REF. That is, the quality of the recycled aggregate can be linked to the type of crushed material.

Figure 6 shows the results obtained for the modulus of elasticity test. The concrete produced with ARCI showed a statistically inferior result when compared to the others at 28 days, approximately $17 \%$ lower than the T REF. However, at 90 and 180 days, this behavior was not observed. At these stages (90 and 180 days) all concrete variants showed statistically similar behavior. Only for the T 30 ARCI line could a decrease in the elasticity modulus of the concrete be observed after 180 days of immersion in saline solution. 


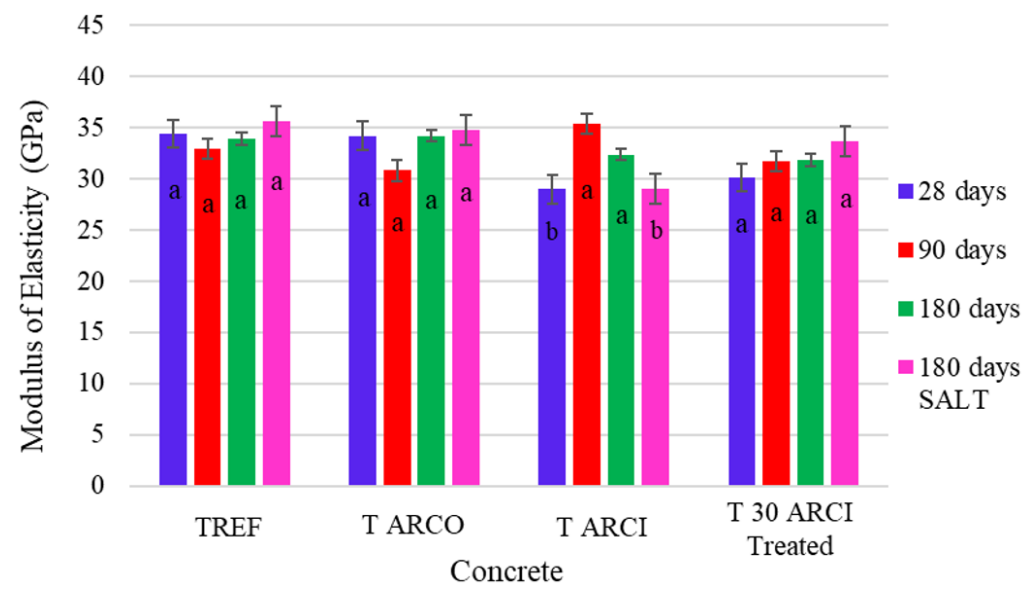

Figure 6. Results of modulus of elasticity.

McGinnis et al. [2] pointed out a $26.4 \%$ reduction in the modulus of elasticity for concrete produced with $50 \%$ recycled aggregate, and a $34.4 \%$ decrease for concretes with a $100 \%$ substitution content. The reduction observed by McGinnis et al. [2] was higher than that obtained in this study, but this is justified by the fact that the researchers used a higher percentage of substitution of the natural aggregate than that used in this research.

\subsection{Indirect durability measurements tests}

\subsubsection{Water absorption capacity by immersion and capillarity}

The main factor that affects the durability of concrete is the entry of gases and liquids into its interior. The ease of entry of deteriorating agents is linked to the useful life of the structure.

Figure 7 shows the water absorption capacity for all of the immersed concrete variants. It is observed that, at 28 days, the T REF showed a water absorption capacity by immersion higher than the concrete variants with recycled aggregate, and this behavior was not maintained at the later stages, when the water absorption capacity by immersion was higher for mixtures with recycled aggregates. It should be noted that the maximum absorption capacity obtained was $6 \%$.

After 180 days of saline immersion, the concrete variants produced with recycled aggregate had a lower water absorption capacity than T REF. This behavior can be explained by the pore structure of the concrete, that is, the concrete variants produced with recycled aggregate are more porous, and when immersed in saline, they tend to absorb sodium chloride more easily and consequently, it solidifies and crystallizes inside the pores, filling voids and thus decreasing its water absorption capacity by immersion.

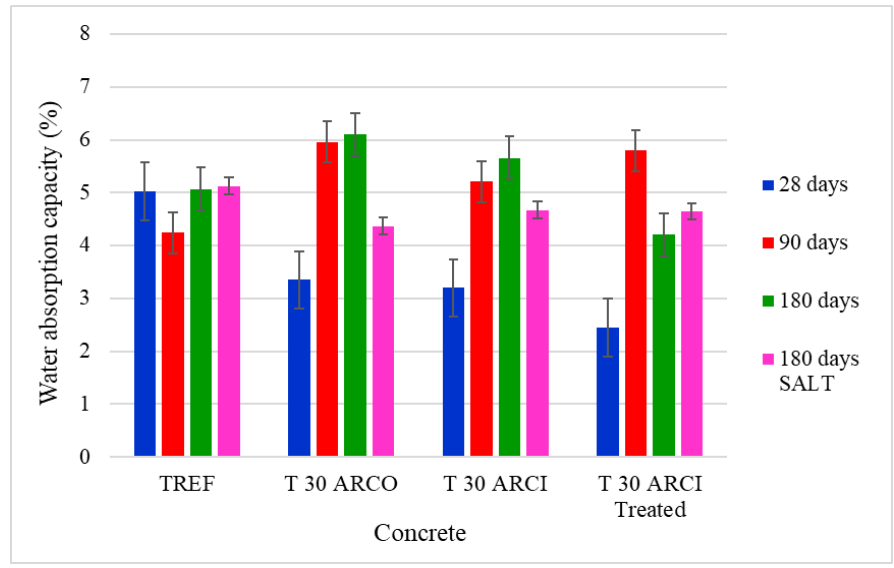

Figure 7. Results of water absorption capacity by immersion. 
In this study it was observed that the water absorption capacities by immersion of the concrete variants using recycled aggregate were higher than those obtained for the reference concrete (TREF), consistent with the results of Troian [47].

Cenalmor et al. [19] pointed out that the substitution of natural aggregate for recycled aggregate should not be higher than $20 \%$, since with this substitution content, the authors obtained a water absorption capacity by immersion of around 5.7\%, a value close to the Instrucción Española del Hormigón Estructural (EHE-08). The water absorption capacity values for the present study reached a maximum value of $6 \%$.

The results of water absorption by capillarity are shown in Figure 8, where the capillarity coefficient of 72 hours of each mix was observed at each test stage.

At the 28 days stage, the capacity of water absorption by capillarity of the T REF was greater than for the other variants. After this stage, the mixtures produced with recycled aggregate presented greater capillarity coefficients.

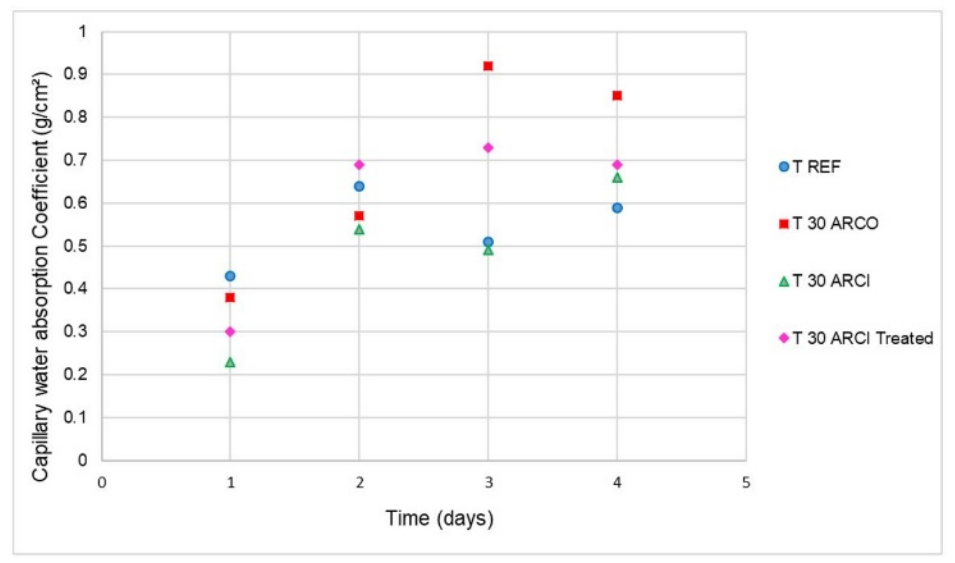

Figure 8. Results of capillary water absorption capacity.

\subsubsection{Permeaability}

The results of the air permeability test, performed with the Porosiscope equipment, are shown in Table 6 .

In Table 6, it is possible to observe that even the concrete using natural aggregate (T REF) did not present a good classification regarding its permeability to air, being classified as moderate and presenting results between 30 and $100 \mathrm{~s}$.

Table 6. Results of permeability test by the Porosiscope equipment.

\begin{tabular}{ccc}
\hline & Permeability & Classification \\
\hline Concrete & Time (s) & Moderate \\
\hline T REF & 55.5 & Poor \\
\hline T 30 ARCO & 21.5 & Poor \\
\hline T 30 ARCI & 17.25 & Poor \\
\hline T 30 ARCI Treated & 17.25 & \\
\hline
\end{tabular}

The results obtained in the present study are inferior to those obtained by Cenalmor et al. [19]. All other concrete mixes produced in the present study were classified as poor in terms of air permeability. However, the a/c ratio, used by Cenalmor et al. [19] (0.5), was lower than that used in this study (0.6). It is observed that the reference concrete (T REF) presented a better result than the mixtures using recycled aggregate, since it took the air approximately three times longer to flow through the pores compared to the mixtures produced with recycled aggregate.

When comparing the mixtures with recycled aggregate to each other, the T $30 \mathrm{ARCO}$ showed the best behavior. 


\subsubsection{Determination of carbonation depth}

Table 7 presents the results obtained from the carbonation test, with the results of carbonated area and average thickness of carbonation, the photographs of the specimen after the spraying of phenolphthalein, and the image drawn in the AutoCAD® program.

It can be observed that the carbonated area of the mixture produced with recycled concrete aggregate (T $30 \mathrm{ARCO})$ presented a better result, that is, it suffered less aggression than the mixture produced with recycled aggregate ( $\mathrm{T} 30$ ARCI and T 30 ARCI Treated). As expected, the reference concrete (T REF) obtained the smallest carbonated area.

In turn, when comparing T $30 \mathrm{ARCI}$ and T $30 \mathrm{ARCI}$ Treated, it is notable that for this determination, the treatment was effective.

Silva and Andrade [30] and Pedro et al. [31] note that concrete using recycled aggregates have a high porosity when compared to concretes that use natural aggregate, and that this characteristic has a significant influence on the carbonation process. According to the authors, at later stages, the depth of carbonation obtained was greater.

Pedro et al. [31] presented results of carbonation depth at 91 days. For concrete using natural aggregate, the depth reached $5.0 \mathrm{~mm}$, while concrete using recycled aggregate had values between 6.2 to $10.6 \mathrm{~mm}$. It is worth mentioning that the determination of the carbonation depth was defined by the authors as being measured after 91 days in a carbonation chamber, with a constant temperature of $20{ }^{\circ} \mathrm{C}$ and carbon dioxide concentration of $5+/-1 \%$. They [23] also found that even though the carbonation depths were greater for concrete variants produced with recycled aggregate, the differences in depth for the natural aggregate concrete variants were between 3 and $6 \mathrm{~mm}$. In this work, the carbonation thickness of all mixtures did not exceed $6 \mathrm{~mm}$, confirming the results obtained by NBR 7211 [23].

Table 7. Results of carbonation test.

\begin{tabular}{|c|c|c|c|c|}
\hline Sample & Sample Photo & Image Analysis & $\begin{array}{c}\text { Carbonated area } \\
\left(\mathrm{cm}^{2}\right)\end{array}$ & e (mm) \\
\hline T REF & & & 1.96 & 1.27 \\
\hline T 30 ARCO & & & 2.57 & 1.65 \\
\hline T 30 ARCI & & & 8.02 & 5.24 \\
\hline $\begin{array}{c}\text { T } 30 \text { ARCI } \\
\text { Treated }\end{array}$ & & i & 4.83 & 3.12 \\
\hline
\end{tabular}

e: average carbonation thickness.

\subsubsection{Determination of chloride penetration}

The results of the chloride penetration test (area, thickness of penetration, photographs taken after spraying silver nitrate solution and the drawn images) are shown in Table 8.

In this case, T $30 \mathrm{ARCO}$ and T $30 \mathrm{ARCI}$ had an ion penetration area smaller than the T REF. It is noted that in neither case did the penetration thickness exceed $15 \mathrm{~mm}$. It is worth mentioning that the concrete variants produced for this work meet the aggressiveness classes 1 and 2 of the NBR 12655 standard [48]. For these two classes of aggressiveness, NBR 6118 [12] defines respective minimum coverages of 20 and $25 \mathrm{~mm}$ for slabs, 25 and $30 \mathrm{~mm}$ for beam / columns, and $30 \mathrm{~mm}$ for structural elements in contact with the ground. In addition to the minimum coverage, 
the minimum coverage plus the execution tolerance, which must be at least another $10 \mathrm{~mm}$, must also be added in the construction of the structure.

Table 8. Results of chloride penetration test.

\begin{tabular}{|c|c|c|c|c|}
\hline Sample & Sample Photo & Image Analysis & $\begin{array}{c}\text { Carbonated Area } \\
\left(\mathrm{cm}^{2}\right)\end{array}$ & e (mm) \\
\hline T REF & & & 17.60 & 11.89 \\
\hline T 30 ARCO & & & 10.89 & 7.19 \\
\hline T 30 ARCI & & & 15.24 & 10.22 \\
\hline $\begin{array}{l}\text { T } 30 \text { ARCI } \\
\text { Treated }\end{array}$ & & & 18.76 & 12.76 \\
\hline
\end{tabular}

e: average carbonation thickness.

Thus, until the end of the 180-day period, none of the concrete variants had a greater carbonation thickness and chloride penetration thickness than the minimum coverage required by the Brazilian standard.

\subsubsection{Chloride migration}

Figure 9 shows the monitoring of electric current during the chloride migration test. It was observed that the behavior of the electric current in the chloride migration test was similar for all concrete variants. Initially, the current measured in the test was zero mA and gradually increased until it reached its peak, before then decreasing until the value reached was practically zero mA. Medeiros [45] found that the greater the peak of the current, the greater the ease with which the electrical current was able to travel through the concrete, meaning that the material has greater permeability. In this case, the highest peak current was presented by the T $30 \mathrm{ARCI}$, followed by the treated T $30 \mathrm{ARCI}$. As for the air permeability, carbonation and chloride penetration tests, the T 30 ARCO presented the best behavior, that is, the lowest current peak, even lower than the reference (T REF).

In addition to monitoring the electric current, this test also made it possible to calculate the concentration of chloride in the anode compartment, the results of which are shown in Figure 10. The concentration of chlorides showed a result similar to that obtained at peak current. The lowest concentration of chloride was obtained by T $30 \mathrm{ARCO}$, followed 
by T REF. The concrete variants with recycled aggregate type ARCI and ARCI Treated obtained similar and higher results, indicating greater permeability to the passage of ions. For the tests of indirect measurement of durability, it is notable that the T 30 ARCO variant presented the best behavior when compared to the other concrete variants that used recycled aggregates. In several tests, this behavior was even better than the reference concrete (T REF).

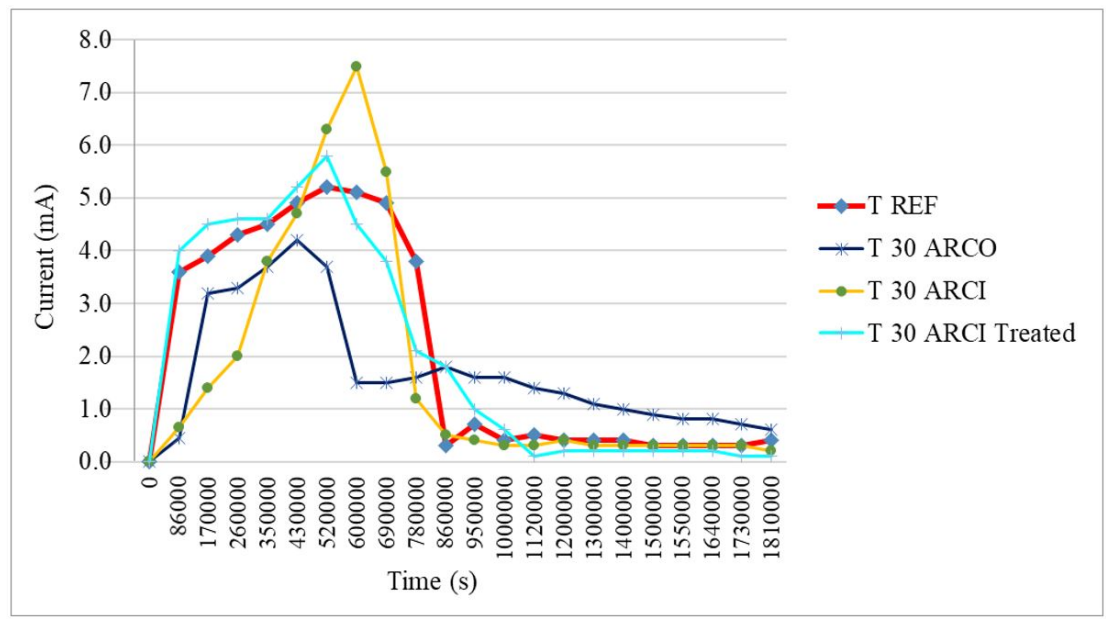

Figure 9. Monitoring of electrical current during chloride migration test.

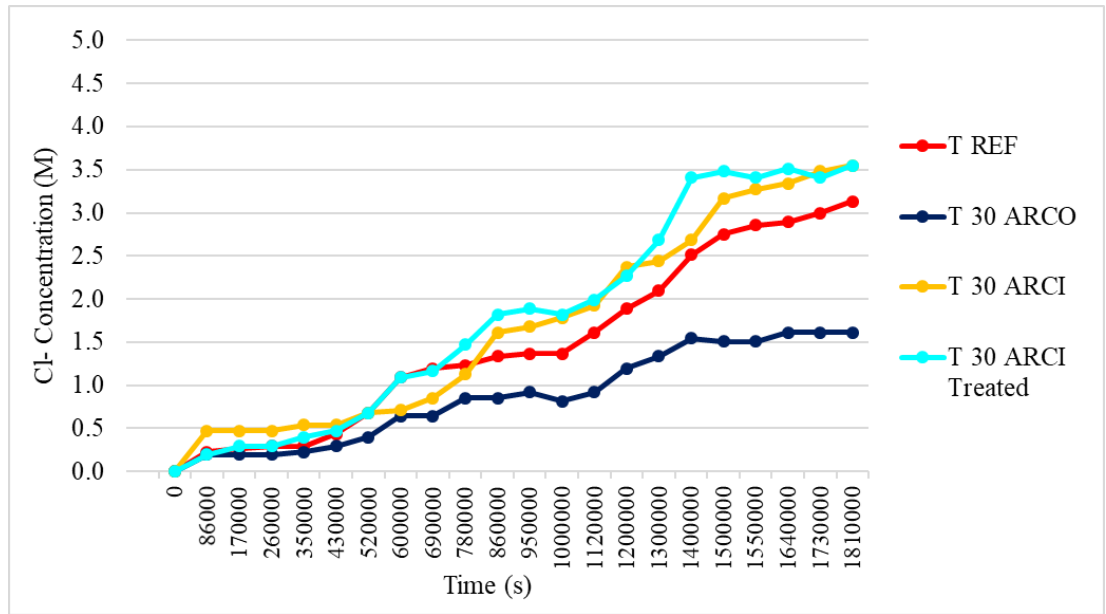

Figure 10. Chloride concentration in the anode compartment.

\section{CONCLUSIONS}

In view of the materials and test conditions of the present study, it can be concluded that:

- The use of coarse recycled concrete aggregate (ARCO) up to a content of $30 \%$ to replace natural aggregate does not change the resistance to axial compression.

- There is a decrease in the resistance to axial compression when using ARCI and ARCI-treated aggregates; however, all concrete types reached the desired strength class C30.

- The elastic modulus of all variants showed statistically equal values for the most advanced stages, from 90 and 180 days.

- Regarding the tests of indirect durability measurement, it is notable that the results obtained by the mix produced with recycled concrete aggregate (T $30 \mathrm{ARCO}$ ) presented better behavior in the face of attacks, including, in some cases, where the behavior of the T 30 ARCO was better than T REF.

- Regarding the migration of chloride ions, the T 30 ARCO concrete showed a lower index, showing better performance than the T REF. 
- There was no improvement in the characteristics of the concrete produced with the treated cementitious aggregate (T 30 ARCI Treated) when compared to the concrete produced with cementitious aggregate (T 30 ARCI), indicating that this treatment is not viable.

Although the concrete produced with recycled concrete aggregate (ARCO) stood out over the others, this does not indicate that the use of cement aggregate (ARCI) is impracticable, and that this recycled aggregate does not guarantee adequate characteristics for concrete with structural functionality.

\section{ACKNOWLEDGEMENTS}

This work was carried out with the support of the Coordination for the Improvement of Higher Education Personnel—Brazil—CAPES and São Paulo Research Foundation (FAPESP).

\section{REFERENCES}

[1] World Business Council for Sustainable Development, The Cement Sustainability Initiative, 2009. Available: https://www.wbcsdcement.org/pdf/CSI-RecyclingConcrete-Summary.pdf (accessed Feb. 2, 2017).

[2] M. J. McGinnis, M. Davis, A. de la Rosa, B. D. Weldon, and Y. C. Kurama, "Strength and stiffness of concrete with recycled concrete aggregates," Constr. Build. Mater., vol. 154, no. 15, pp. 258-269, Nov 2017, http://dx.doi.org/10.1016/j.conbuildmat.2017.07.015.

[3] M. Omrane, S. Kenai, E.-H. Kadri, and A. Aït-Mokhtar, "Performance and durability of self-compacting concrete using recycled concrete aggregates and natural pozzolan," J. Clean. Prod., vol. 165, pp. 415-430, Nov 2017, http://dx.doi.org/10.1016/j.jclepro.2017.07.139.

[4] V. Afroughsabet, L. Biolzi, and T. Ozbakkaloglu, "Influence of double-hooked-end steel fibers and slag on mechanical and durability properties of high performance recycled aggregate concrete," Compos. Struct., vol. 181, pp. 273-284, Dec 2017, http://dx.doi.org/10.1016/j.compstruct.2017.08.086.

[5] L. D. Poulikakos et al., "Harvesting the unexplored potential of European waste materials for road construction," Resour. Conserv. Recycling, vol. 116, pp. 32-44, Jan 2017, http://dx.doi.org/10.1016/j.resconrec.2016.09.008.

[6] São Paulo. Secretária do Meio Ambiente, Plano de Resíduos Sólidos do Estado de São Paulo. São Paulo: SMA, 2015. [Online]. Available: http://www.cetesb.sp.gov.br

[7] P. Gonçalves and J. Brito, "Recycled Aggregate Concrete (RAC) - comparative analysis of existing specifications," Mag. Concr. Res., vol. 62, no. 5, pp. 339-346, May 2010, http://dx.doi.org/10.1680/macr.2008.62.5.339.

[8] Associação Brasileira de Normas Técnicas, Agregados Reciclados de Resíduos Sólidos da Construção Civil - Utilização em Pavimentação e Preparo de Concreto Sem Função Estrutural - Requisitos, ABNT NBR 15116, 2004.

[9] P. M. Mehta and P. M. J. Monteiro, Concreto: Estrutura, Propriedades e Materiais, 2nd ed. São Paulo: PINI, 2008.

[10] D. H. Nguyen, M. Boutouil, N. Sebaibi, F. Baraud, and L. Leleyter, "Durability of pervious concrete using crushed seashells," Constr. Build. Mater., vol. 135, pp. 137-150, Mar 2017, http://dx.doi.org/10.1016/j.conbuildmat.2016.12.219.

[11] R. V. Silva and J. Brito, "Use of recycled aggregates from construction and demolition wastes in the production of structural concrete," in EURO ELECS, 2015, pp. 1-15.

[12] Associação Brasileira de Normas Técnicas, Projeto de Estruturas de Concreto - Procedimento, ABNT NBR $6118,2014$.

[13] International Organization for Standardization, General Principles on the Design of Structures for Durability, ISO 13.823, 2008.

[14] J. P. Ollivier and A. Vichot, Durabilidade do Concreto - Bases Científicas para a Formulação de Concretos Duráveis de Acordo com o Ambiente. São Paulo: Ed. Jean-Pierre Olivvier e Angélique Vichot, 2014.

[15] D. Zhang and Y. Shao, "Effect of early carbonatation curing on chloride penetration and weathering carbonation in concrete," Constr. Build. Mater., vol. 123, pp. 516-526, Oct 2016, http://dx.doi.org/10.1016/j.conbuildmat.2016.07.041.

[16] T. C. Santos, “Otimização do método Cembureau de ensaio de permeabilidade ao gás para materiais cimentícios," Ph.D. dissertation, Prog. Pós-grad. Eng. Apl. Sust., Inst. Fed. Ed., Ciênc. Tecnol. Goiano, Rio Verde, 2019.

[17] G. F. Rizzo, "Durability of concretes with recycled aggregates,” Ph.D. dissertation, Prog. Pós-grad. Sist. Infraestrut. Urb., Pontif. Univ. Catol. Campinas, Campinas, 2018.

[18] C. Medina, W. Zhu, T. Howind, M. I. Sánchez de Rojas, and M. Frías, "Influence of mixed recycled aggregate on the physical e mechanical properties of recycled concrete," J. Clean. Prod., vol. 68, pp. 216-225, Apr 2014, http://dx.doi.org/10.1016/j.jclepro.2014.01.002.

[19] M. M. Cenalmor, D. Estévez, and M. C. Gonzalez, "Estudio de la durabilidad em hormigones con áridos reciclados procedentes de piezas pré-fabricadas," in PATORREB, 2015, pp. 1-15. 
[20] C.-C. Fan, R. Huang, H. Hwang, and S.-J. Chao, "Properties of concrete incorporating fine recycled aggregates from crushed concrete wastes," Constr. Build. Mater., vol. 112, pp. 708-715, Jun 2016, http://dx.doi.org/10.1016/j.conbuildmat.2016.02.154.

[21] A. Sucic and A. Lotfy, "Effect of new paste volume on performance of structural concrete using coarse and granular recycled concrete aggregate of controlled quality," Constr. Build. Mater., vol. 108, pp. 119-128, Apr 2016, http://dx.doi.org/10.1016/j.conbuildmat.2015.10.064.

[22] M. Perea and A. Alvarado "Propriedades mecânicas en concretos fabricados con agregados gruesos reciclados tratados com lechadas," in CONPAT, 2015, pp. 1-14.

[23] Associação Brasileira de Normas Técnicas, Agregados para Concreto - Especificação, ABNT NBR 7211, 2009.

[24] Associação Brasileira de Normas Técnicas, Agregado Miúdo - Determinação da Massa Específica e Massa Específica Aparente, ABNT NBR NM 52, 2009.

[25] Associação Brasileira de Normas Técnicas, Agregado Graúdo - Determinação da Massa Específica, Massa Específica Aparente e Absorção de Água, ABNT NBR NM 53, 2009.

[26] Associação Brasileira de Normas Técnicas, Agregado Miúdo - Determinação da Absorção de Água, ABNT NBR NM $30,2001$.

[27] Associação Brasileira de Normas Técnicas, Agregados - Determinação da Resistência ao Esmagamento de Agregados Graúdos, ABNT NBR 9938, 1987.

[28] Associação Brasileira de Normas Técnicas, Agregados - Determinação da Composição Granulométrica, ABNT NBR NM 248, 2003.

[29] P. Helene and P. Terzian, Manual de Dosagem e Controle do Concreto. São Paulo: Pini, 1992.

[30] S. R. Silva and J. J. O. Andrade, "Investigation of mechanical properties and carbonation of concretes with construction and demolition waste and fly ash," Constr. Build. Mater., vol. 153, pp. 704-715, Oct 2017, http://dx.doi.org/10.1016/j.conbuildmat.2017.07.143.

[31] D. Pedro, J. Brito, and L. Evangelista, "Structural concrete with simultaneous incorporation of fine and coarse recycled concrete aggregates: mechanical, durability and long-term properties," Constr. Build. Mater., vol. 154, pp. 294-309, Nov 2017, http://dx.doi.org/10.1016/j.conbuildmat.2017.07.215.

[32] D. Xuan, B. Zhan, and C. S. Poon, "Durability of recycldes aggregate concrete prepared with carbonated recycled concrete aggregates," Cement Concr. Compos., vol. 84, pp. 214-221, Nov 2017, http://dx.doi.org/10.1016/j.cemconcomp.2017.09.015.

[33] Associação Brasileira de Normas Técnicas, Concreto - Determinação da Consistência pelo Abatimento do Tronco de Cone, ABNT NBR NM 67, 1998.

[34] Associação Brasileira de Normas Técnicas, Concreto Fresco - Determinação da Massa Específica, do Rendimento e do Teor de Ar pelo Método Gravimétrico, ABNT NBR 9833, 2009.

[35] Associação Brasileira de Normas Técnicas, Concreto - Ensaio de Compressão de Corpos de Prova Cilíndricos, ABNT NBR 5739, 2007.

[36] Associação Brasileira de Normas Técnicas, Concreto - Determinação do Módulo Estático de Elasticidade à Compressão, ABNT NBR 8522, 2008.

[37] Associação Brasileira de Normas Técnicas, Argamassa e Concreto Endurecidos - Determinação da Absorção de Água, Índice de Vazios e Massa Especifica, ABNT NBR 9778, 2005.

[38] Associação Brasileira de Normas Técnicas, Argamassa e Concreto Endurecidos - Determinação da Absorção de Água por Capilaridade, ABNT NBR 9779, 2012.

[39] C. B. França, “Avaliação de cloretos livres em concretos pelo método de aspersão de solução de nitrato de prata," Ph.D. dissertation, Univ. Catol. Pernambuco, Recife, 2011.

[40] M.-Y. Kim, E.-I. Yang, and S.-T. Yi, "Application of the colorimetric method to chloride diffusion evaluation in concrete structures," Constr. Build. Mater., vol. 41, pp. 239-245, Apr 2013, http://dx.doi.org/10.1016/j.conbuildmat.2012.11.084.

[41] L. V. Real, D. R. B. Oliveira, T. Soares, and M. H. F. Medeiros, "Método colorimétrico por aspersão de nitrato de prata para avaliação da penetração de cloretos em concreto: estado da arte," Rev. ALCONPAT, vol. 5, no. 2, pp. 149-159, May 2015, http://dx.doi.org/10.21041/ra.v5i2.84.

[42] American Society for Testing and Materials, Porosiscope ${ }^{\mathrm{TM}}$ Determines Air and Water Permeability in Concrete Both At and Below the Surface, 2020. [Online]. Available: http://www.ndtjames.com/Porosiscope-p/c-p.htm

[43] S. Valls and E. Vàzquez, "Accelerated carbonatation of sewage sluge-cementsand mortars and its environmental impact," Cement Concr. Res., vol. 31, no. 9, pp. 1271-1276, Sep 2001, http://dx.doi.org/10.1016/S0008-8846(01)00573-7.

[44] J. M. Gandía-Romero et al., "Potentiometric thick-film sensor for measuring the pH of concrete," Cement Concr. Compos., vol. 68, pp. 66-76, Apr 2016, http://dx.doi.org/10.1016/j.cemconcomp.2016.02.006.

[45] R. A. Medeiros Jr., "Estudo da resistividade do concreto para proposta de modelagem de vida útil - corrosão das armaduras devido a penetração de cloreto,” Ph.D. dissertation, Inst. Tecnol. Aeronáut., São José dos Campos, 2011. 
[46] American Society for Testing and Materials, Standard Test Method for Electrical Indication of Concrete Ability to Resist Chloride Ion Penetration, ASTM C 1202-05, 2005.

[47] A. Troian, "Avaliação da durabilidade de concretos produzidos com agregado reciclado de concreto frente à penetração de cloreto," M.S. thesis, Univ. Vale do Rio dos Sinos, São Leopoldo, 2010.

[48] Associação Brasileira de Normas Técnicas, Concreto de Cimento Portland-Preparo, Controle, Recebimento e Aceitação Procedimento, ABNT NBR 12655, 2015.

Author contributions: LLP: conceptualization, funding acquisition, supervision; GRF: writing; conceptualization, data curation; AEPGAJand PSPF: formal analysis, methodology.

Editors: José Luiz Antunes de Oliveira e Sousa, Guilherme Aris Parsekian. 